\title{
Improving Marine Water Quality by Mussel Farming: A Profitable Solution for Swedish Society
}

\begin{abstract}
Eutrophication of coastal waters is a serious environmental problem with high costs for society globally. In eastern Skagerrak, reductions in eutrophication are planned through reduction of nitrogen inputs, but it is unclear how this can be achieved. One possible method is the cultivation of filter-feeding organisms, such as blue mussels, which remove nitrogen while generating seafood, fodder and agricultural fertilizer, thus recycling nutrients from sea to land. The expected effect of mussel farming on nitrogen cycling was modeled for the Gullmar Fjord on the Swedish west coast and it is shown that the net transport of nitrogen (sum of dissolved and particulate) at the fjord mouth was reduced by $20 \%$. Existing commercial mussel farms already perform this service for free, but the benefits to society could be far greater. We suggest that rather than paying mussel farmers for their work that nutrient trading systems are introduced to improve coastal waters. In this context an alternative to nitrogen reduction in the sewage treatment plant in Lysekil community through mussel farming is presented. Accumulation of bio-toxins has been identified as the largest impediment to further expansion of commercial mussel farming in Sweden, but the problem seems to be manageable through new techniques and management strategies. On the basis of existing and potential regulations and payments, possible win-win solutions are suggested.
\end{abstract}

\section{INTRODUCTION}

Eutrophication of coastal waters, which causes increased primary production and often leads to hypoxia, is a serious environmental problem in many places worldwide $(1,2)$. In the NE Atlantic region, i.e. the Skagerrak coastal waters (Fig. 1), eutrophication threatens fish production, and marine biodiversity $(3,4)$. The international goal of reducing nitrogen and phosphorus from anthropogenic, land-based sources to the sea by 50\% between 1985 and 2005 (North Sea and OSPAR Conventions, 1992) will not be reached. The Swedish national goal for release of anthropogenic waterborne nitrogen is a $40 \%$ reduction from the 1995 level before 2025 . The County Board of Västra Götaland, Sweden, has established a goal of reducing waterborne nitrogen flows to the coastal waters of eastern Skagerrak by $18 \%$ of the 1995 level by 2010, equal to 2750 tonnes per year (5). Another important source is atmospheric deposition, which contributes almost $25 \%$ of the total influx of nitrogen.

The extent of the problem in a historical perspective is hard to document, since the main increase in nutrient load occurred before monitoring programs started. However, the EU project Forum Skagerrak (4) has conservatively estimated the increase in load from land and atmosphere to the Baltic and North Sea regions, including the Skagerrak, to be fourfold in phosphorus from the 1940s to the 1970s and twofold in nitrogen from the

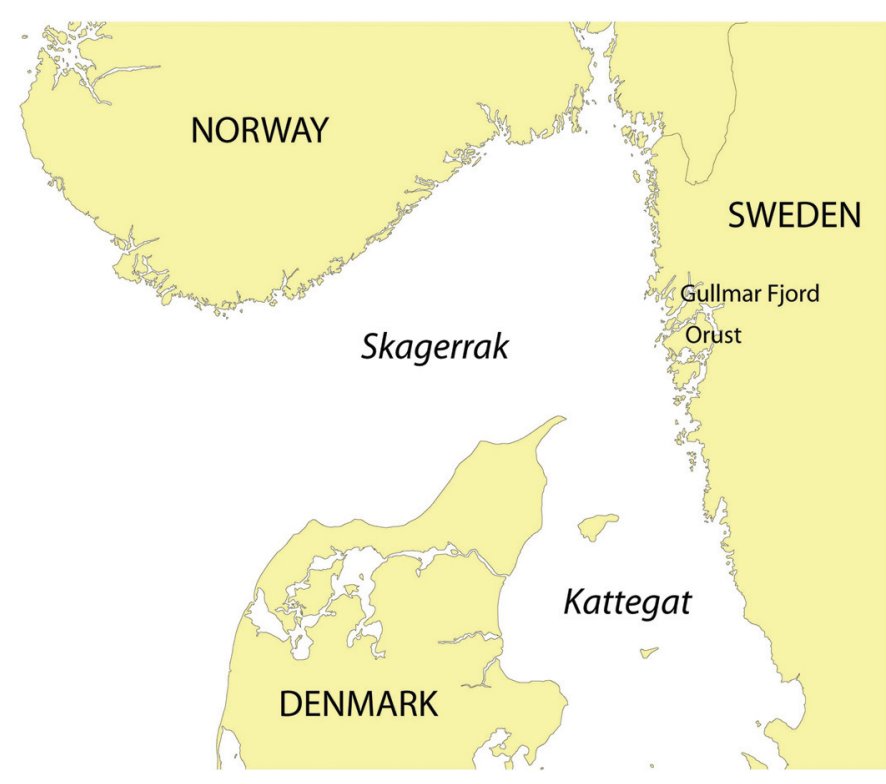

Figure 1. Map showing Swedish Skagerrak coast.

1950 s to the 1980s. During the last decades, nitrogen inputs have been consistent, but phosphorous inputs have exhibited a slight decrease (4).

Of the total anthropogenic waterborne supply of nitrogen to the Swedish Skagerrak waters, roughly $20 \%$ or 2200 tonnes come from point sources like municipal wastewater and industries, and the rest, about 8500 tonnes, from diffuse sources like agriculture (6). The most obvious measures for reducing nutrient loads, such as upgrading large water-treatment plants to comply with EU regulations and reducing emissions from large industries, have now been implemented, but with insufficient effect on the overall situation (4). Other measures, such as changes in agricultural practices and the restoration of wetlands, have also been implemented, but again with insufficient results to date (7).

Harvesting filter-feeding organisms such as blue mussels (Mytilus edulis) that feed on phytoplankton may be a sustainable method for producing food of high nutritional value while simultaneously recycling nutrients from sea to land. This possibility has been discussed by several authors (8-10). Reduction of the impact of anthropogenic nutrients can be achieved by reducing the amount of seston, including phytoplankton, in the coastal water. Seston is the basic diet of the filter-feeding mussels; hence by placing mussel cultures in the area and harvesting the production, the amount of seston in the water is reduced at the same time as nutrients are removed.

The aim of this paper is to evaluate the following hypothesis: Mussel farming can act both as sustainable food production and as a cost-effective method to improve coastal water quality. 


\section{METHODS AND CONDITIONS}

\section{Biological Background}

The study area (eastern Skagerrak, Swedish west coast) is shown in Figure 1. Presently about 1500 tonnes (t) of mussels per year (11) are cultured and harvested in the area, resulting in a removal of about $15 \mathrm{t}$ of nitrogen, considering the nitrogen content is $1 \%$ of the wet weight (12). In general, the eastern Skagerrak area offers excellent conditions for the cultivation of blue mussels according to the Swedish Aquaculture Association (Anders Granhed, pers. comm.). The annual mean primary production measured during the period 1985-1999 at the mouth of the Gullmar Fjord, a site which is representative for the eastern Skagerrak coastal zone, was calculated to $248 \mathrm{gC} \mathrm{m}^{-2} \mathrm{yr}^{-1}$ (13), showing that there is good potential for mussel growth (14). The supply of $M$. edulis larvae is never a limiting factor and there are suitable farm sites available. The period from settlement to cultured mussels with a shell length of 5-6 cm is comparable to growth rates in other European states (14).

\section{Long-line Mussel Farming}

There are many ways of farming mussels. This paper focuses on the long-line approach developed in Sweden in the early 1980s (15). The mussels are grown on vertical 6-m suspenders attached to horizontal lines (Fig. 2). Normally settlement occurs abundantly in June (about 2500-10 000 ind. $\mathrm{m}^{-1}$ suspender) along the Skagerrak coast. After 17-18 months, when the culture is ready to harvest, about 500 ind. $\mathrm{m}^{-1}$ remain (14).

The gross production capacity of an average Swedish longline unit is about 140 to $180 \mathrm{t}$ of mussels in 18 months (15, 16). Each unit, consisting of $8-10$ lines, occupies a water surface area of about $2000 \mathrm{~m}^{2}$ and acts as a large three-dimen-

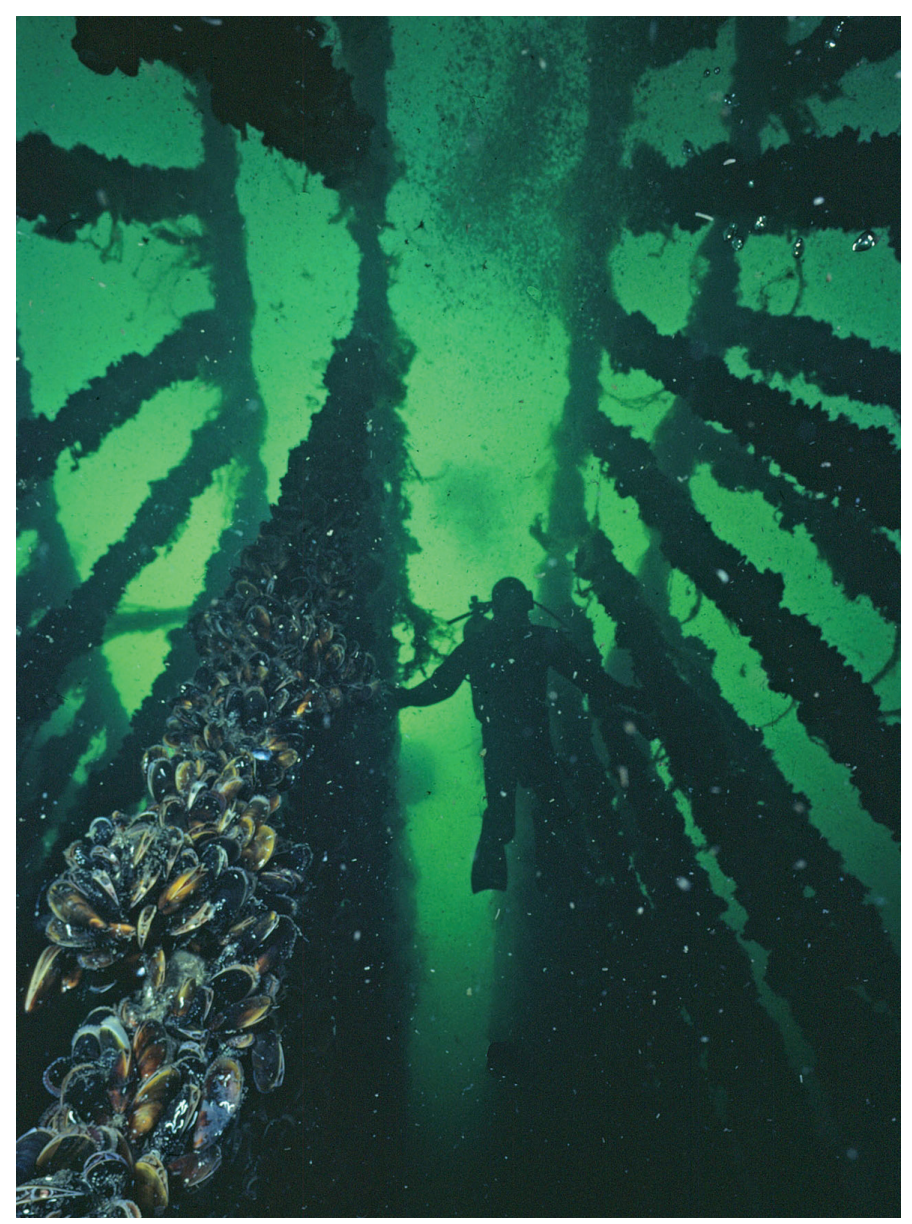

Figure 2. Underwater view of a long-line mussel farm carrying mussels ready for harvesting. Photo: T. Holm. sional bio-filter $(10 \times 200 \mathrm{~m}, \sim 6 \mathrm{~m}$ deep). An optimal site at the Swedish West Coast produces up to $40 \mathrm{~kg}$ of fresh mussels $\mathrm{m}^{-2}$ and $\mathrm{yr}^{-1}$, while filtering the phytoplankton biomass produced by about $25 \mathrm{~m}^{2}$ of sea surface. Each farm unit of 2000 $\mathrm{m}^{2}$ will thus filter the surface water from about $50000 \mathrm{~m}^{2}(5$ ha) (9). In order to maximize the rate of biomass removal, mussels should be harvested during the months November to December at an age of 17-18 months (14). However, other factors, such as marketing and toxicity, generally require more complex strategies.

Apart from space, the two main interrelated ecological factors limiting the size of mussel cultures are seston concentration and current speed (14). For good growth to be maintained, an increase in the number of long-lines depends on a corresponding increase in the average current speed or a commensurate increase in the quantity of food. The hydrodynamic environment in terms of horizontal advective processes must also be favorable for energy transfer from the pelagic ecosystem to this artificial benthic habitat.

\section{Licensing - Lysekil Area}

There are numerous sites along the Skagerrak coast that are suitable for mussel farming, according to the criteria: availability, reasonable wind protection, water depths between 6 and $25 \mathrm{~m}$ and average current speeds of more than $5 \mathrm{~cm} \mathrm{~s}^{-1}$. Shipping, yachting, fishing sites, tourism and beaches for swimming also have to be taken into consideration. In addition, the economic rights of the waters within $300 \mathrm{~m}$ from land belong to the owner of the land and an aquaculture development has to be agreed upon by the landowner and the farmer. To minimize the risk for conflict, it is important to inform local people and to consider their views (17). When this is done, obtaining a farm license is normally not a problem.

The sewage treatment plant of Lysekil, situated at the Gullmar Fjord (Fig.1), presently releases nearly 40 t of nitrogen per year into the sea. There are plans to remove $28 \mathrm{t}$ of nitrogen $(70 \%)$ in the sewage water treatment plant, in accordance with EU-regulation 91/271/EEG. An alternative method would be to expand mussel farming, where removing $28 \mathrm{t}$ of nitrogen corresponds to an annual production and harvest of $2800 \mathrm{t}$ of mussel biomass, given a nitrogen content of about $1 \%$ in the mussels (12). If the conservative figure of $140 \mathrm{t}$ of production per long-line unit is used, altogether 20 units per year have to be harvested at different locations in the area. The landowners in the area and professional fishermen were briefed about the plans and applications for farm licenses were sent to the fishery unit of the county administration.

\section{Market}

The possibility of reducing nitrogen flows in the coastal waters by means of mussel farming depends largely on the feasibility of forming commercial enterprises, which in turn, depends on the economy and the market. The availability of investors is often a major problem in the Swedish aquaculture sector, but a guaranteed compensation for the nitrogen removal could ease the possibility to receive bank loans. In most cases, new enterprises are started as small-scale operations. As the domestic market for mussel products is small, an expansion of the industry depends on successful exports.

\section{Toxins and Pathogenic Microbes}

Food safety of mussels is regulated in the EU-directive 91/492 EEG. The largest impediment to further development of commercial mussel farming in Sweden is the occurrence of algal toxins especially diarrhoeic shellfish poisoning (DSP), caused 
by diarrhoeic shellfish toxins, DST (18). The symptoms of DSP include severe gastrointestinal problems like diarrhoea, nausea, vomiting and stomach pain (19). The organisms responsible, Dinophysis spp, are unicellular eukaryots whose major toxins are okadaic acid (OA) and a number of structurally related toxins.

To guarantee a more continuous supply of mussels, a reliable method for detoxification of mussels would be useful for mussel farmers (18). Improved knowledge about factors affecting the elimination rate of these toxins is required to develop practical and cost-effective detoxification methods

Health risks associated with consumption of virally contaminated shellfish are well documented $(20,21)$. The symptoms of viral food poisoning are similar to those of DSP but no attempts have been made to distinguish between the sources of the illnesses. The Gram-negative bacteria Escherichia coli is used as an indicator organism for fecal contamination in bivalves, but as is now well documented, the shellfish industry requires a more reliable viral indicator system (22).

\section{The Agro-Aqua Recycling}

To optimize the environmental effect of mussel farming, all organisms attached to the lines should be harvested and brought ashore. Only about $2 / 3$ of harvested mussels are used for human consumption (Scanfjord, pers. comm.). The remainder can be used for Agro-Aqua recycling of nutrients (Fig. 3). The removal of the remainder, consisting of small or damaged mussels, is important for the removal of nitrogen and waterquality improvement. In a field study in the summer of 2003, 5 to $20 \mathrm{tha}^{-1}\left(1 \mathrm{ha}=10000 \mathrm{~m}^{2}\right)$ of the remainder was used as an organic fertilizer in the cultivation of barley.

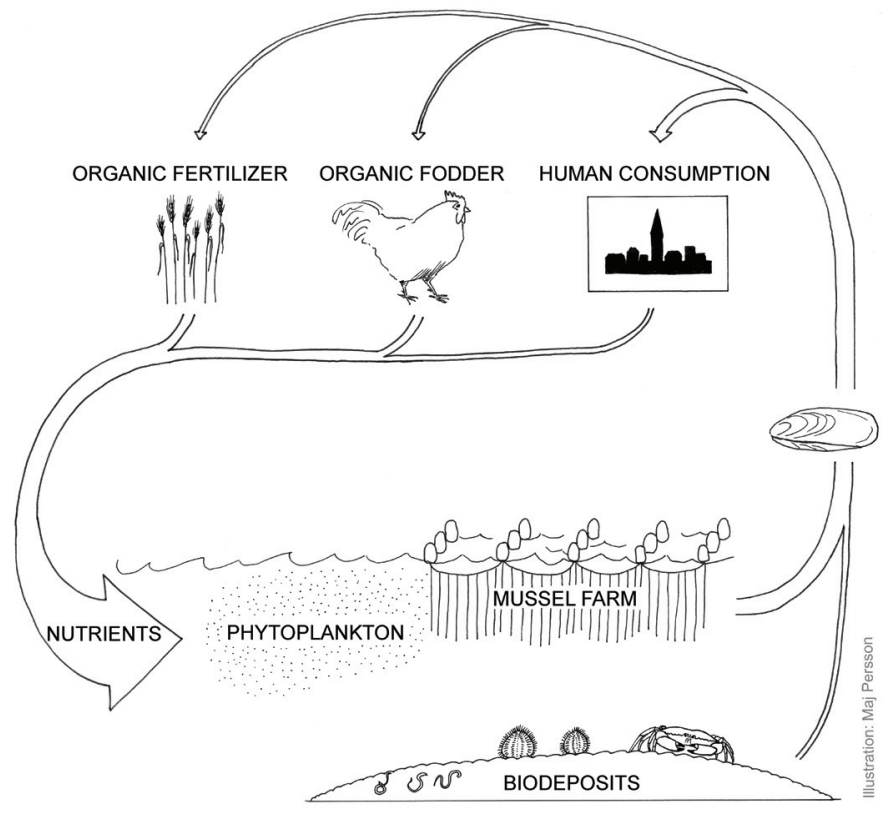

Figure 3. The Agro-Aqua recycling system of nutrients from sea to land.

In order to find new applications for products from mussel farming, a pilot study was conducted whereby mussels were fed to laying hens. Sixty-four hens were fed four different treatments of boiled and chopped mussel meat in their fodder and compared to controls. The number and weight of the eggs were monitored as well as the weight of the hens. The color of the yolk was measured according to a Roche ${ }^{\circledR}$ yolk color indicator and the taste of the eggs compared.

\section{Modelling the Nutrient Uptake of Mussel Farming}

The expected effect of mussel farming on nitrogen cycling was modeled for the Gullmar Fjord on the Swedish west coast. This fjord is $30 \mathrm{~km}$ long, has a sill depth of $45 \mathrm{~m}$ and a maximum depth in the central part of $120 \mathrm{~m}$. A numerical threedimensional biogeochemical model has been developed for the Gullmar Fjord area $(23,24$, see box on page 136). This model was based on $43 \times 12$ horizontal and 40 vertical cells and was validated using monthly or more frequent monitoring data from three areas of the fjord; the mouth, central, and inner part. Comparisons with measurements show that the model was able to simulate temperature, salinity, nutrients $\left(\mathrm{PO}_{4}\right.$, $\mathrm{NO}_{3}, \mathrm{NH}_{4}$ ), oxygen and chlorophyll (= phytoplankton) both horizontally and vertically throughout one year. The model could also reproduce the concentration of zooplankton, sedimentation of PON (Particulate Organic Nitrogen) and benthic accumulation of organic material and nitrogen.

The number of mussels produced in a mussel farm unit is calculated to be $8 \times 10^{6}$ (500 mussels per meter suspender). The total weight of all mussels in one mussel farm is assumed to be $200 \mathrm{t}$. The pumping capacity is $2-3 \mathrm{~L} \mathrm{hr}^{-1}$ per mussel and the pumping capacity of one farm is thus up to $5.6 \mathrm{~m}^{3 \cdot} \mathrm{s}^{-1}$. Some of the mussels are pumping "old" water, which already has been filtered by others. This effect has to be taken into consideration in the case of weak currents, but is less important in situations with strong currents. The model pumping capacity is at its maximum when currents are greater than $0.22 \mathrm{~m} \mathrm{~s}^{-1}$, and decreases logarithmically for currents less than $0.22 \mathrm{~m} \mathrm{~s}^{-1}$.

The water filtered by the mussels is reduced in terms of seston concentration. The out-flowing water from the mussels has unchanged concentrations of phosphate and nitrate, but an increased amount of ammonium $(+18 \%$ of the mussel intake of nitrogen) and detritus ( $+17 \%$ of the mussel intake of nitrogen). The model treats detritus particles from the mussels as seston. When the concentration of plankton in the water mass is computed to be high $\left(>4 \mu \mathrm{g}\right.$ chlorophyll $\left.\mathrm{L}^{-1}\right)$, the mussels cannot digest all the food but reject some filtered plankton as pseudofeces, which in the model sinks as detritus.

\section{RESULTS AND DISCUSSION}

\section{The Rationale for Supporting Mussel Farming}

Commercial mussel producers currently benefit society by the removal of nitrogen from coastal waters, for which they are unrewarded. While this might appear to be advantageous for society, it also presents a lost opportunity. Given the right incentives, these firms could expand the scale of their operations and thus generate much greater benefits. It is also worth noting that an expanded mussel industry could have other benefits and added values, i.e. provide jobs in the region, which is particularly pertinent as coastal fisheries are under pressure due to low fish stocks. A production of $2800 \mathrm{t}$ of mussels will need 5-10 employees depending on how the mussels are processed.

In environmental economics, the nitrogen-removal service that mussel farms provide is known as an "external benefit" to society (25). In the case of mussel production, the benefit of nitrogen-removal is an argument for supporting these firms, for instance by paying them per kilogram of nitrogen removed from the sea.

We suggest that rather than paying mussel farmers for their work, the authorities should impose demands on those who emit the pollution through emission quotas which are traded and bought by the emitter. This is particularly straightforward when nutrients are discharged from a point source, i.e. emissions from a sewage treatment plant or a factory. Nutrient quotas will thus be the currency traded between the market economy 


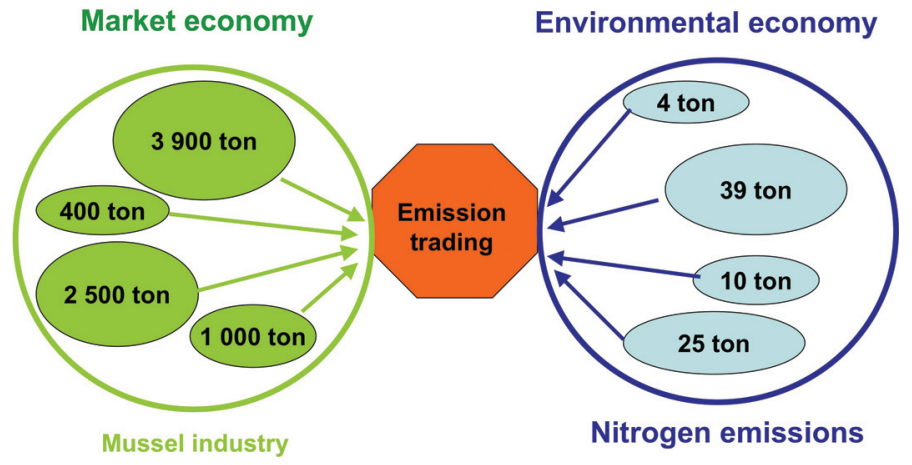

Figure 4. The trading of nutrient quotas is the clutch between the environmental and market economies (tonnes).

and the environmental economy (Fig. 4). Such emissions trading schemes, or tradable quota schemes, were first introduced in 1970 in amendments to the U.S. Clean Air Act (26). Nutrient trading systems are becoming an important issue to improve coastal waters in the United States, where the Environmental Protection Agency is mandated by the Clean Water Act to improve water quality $(27,28)$.

In order for the system to work smoothly, a market is required where sellers and buyers of nutrient quotas can easily do business. In Sweden and Norway, enterprises are under development to manage the trade in quotas and thus ensure that the agreed amounts of nutrients are recycled from sea to land through mussel harvesting. These enterprises may be responsible for all farming and business operations, including marketing and selling the mussel products. Payments should be made per unit of nitrogen that is removed. This approach reduces the financial risk for the nutrient-emitting firm.

The diffuse supply of nutrients can in principle be handled with the same business approach, but in general it will be more difficult to define the buyer (= owner) of a diffuse nutrient quota. Agriculture is a major contributor to the diffuse supply of nutrients to coastal areas. Farmers in Sweden pay environmental tax when using fertilizers and the recycling of nutrients from sea to land could be financed by those taxes. Other financial solutions and partners have to be found for other activities in society with diffuse emissions of nutrients to the environment. Most likely, local or regional administrations will play a key role in this new environment to business networking and trading.

\section{Comparison between Methods of Nitrogen Removal}

Sewage treatment requires limited space, but the energy cost for converting nitrogen compounds to nitrogen gas is rather high. The technical office of the Lysekil community has recently calculated the total annual cost to be slightly more than 262000 USD for the removal of $28 \mathrm{t}$ of nitrogen. The total cost for the transformation of nitrogen in the Lysekil case was estimated to $9.70 \mathrm{USD} \mathrm{kg}^{-1}$ which was considered to be low compared to Öckerö community situated outside Gothenburg, where the cost was calculated to $14.40 \mathrm{USD} \mathrm{kg}^{-1}$ (P. Falck, pers. comm.).

In a large EU-project (29), 47 small ponds on the Swedish west coast were created in order to reduce the nutrient load to the Gullmar Fjord. Together they covered a total area of $250000 \mathrm{~m}^{2}$ and the yearly load reduction to the recipient was estimated to be $16 \mathrm{t}$ of nitrogen and $1 \mathrm{t}$ of phosphorous. The total cost of the investment together with an estimated annual running cost was calculated to $12.40 \mathrm{USD} \mathrm{kg}^{-1}$ of removed nitrogen over a 20 year period. The water retention results in nitrogen compounds being naturally oxidized and finally reduced to nitrogen gas. The drawback is the availability of suitable space, as it is difficult in many places to transform significant areas of land into wetland.

When mussels are used for the removal of nitrogen this is based on a commercial enterprise. The lack of investors in Sweden has been a major reason for the slow development of the Swedish mussel industry (19). Thus, financing the capital costs of establishing the enterprises can be regarded as a minimum level of compensation. For the trading company the charge to the emitter is also to cover the risks involved in harvesting an agreed amount of nitrogen. The trading company would at present have to charge the emitter at least $5.25 \mathrm{USD} \mathrm{kg}^{-1}$ of removed nitrogen, which is the calculated financial cost provided an agreement is reached for a 20 -year period. In a nutrient trading scheme involving mussel farming, it will be rather easy to account for the amount of, e.g. nitrogen removed based on the annual harvest. The flux of $\mathrm{N}_{2}$ from the sediment, as a result of the increased bio-sedimentation from an over-laying mussel farm, could also be traded but in practice, due to the varying conditions at farming sites, it will not be possible to set a fixed $\mathrm{N}_{2}$ removal rate. This extra service of the shellfish farming will require special measurements to be able to trade (27).

The difference between sewage treatment and mussel farming can be regarded from another viewpoint. Harvesting $2800 \mathrm{t}$ of mussels each year would compensate for a nitrogen outflow of $28 \mathrm{t}$ from the municipal sewage treatment plant. This is a reduction of the nitrogen by $70 \%$, postulated in the EU-directive $91 / 271 /$ EEG. Thus, the result is an annual release of $11 \mathrm{t}$ of nitrogen from the sewage plant, which is dispersed to the marine environment. On the other hand, as can be seen from Figures $5 \mathrm{~A}$ and $5 \mathrm{~B}$, another $28 \mathrm{t}$ of nitrogen will sediment and be concentrated directly under the farms. This nitrogen comes not only from the plant but also from other nitrogen sources and since it is concentrated under the farm, it can be dealt with if suitable techniques are developed.

Can landings of fish also be regarded as harvest of nutrients from the sea? It would with no doubt be rather easy to calculate the amount of nitrogen brought ashore in fish. However, according to an EC-legal assessment of mussel farming and nutrient trading systems as instruments for recovering nitrogen from the sea, it is obvious that the "same" nitrogen which has been supplied from a point source has also to be harvested (S. Westerlund, pers. comn.). Consequently, at present, fish caught

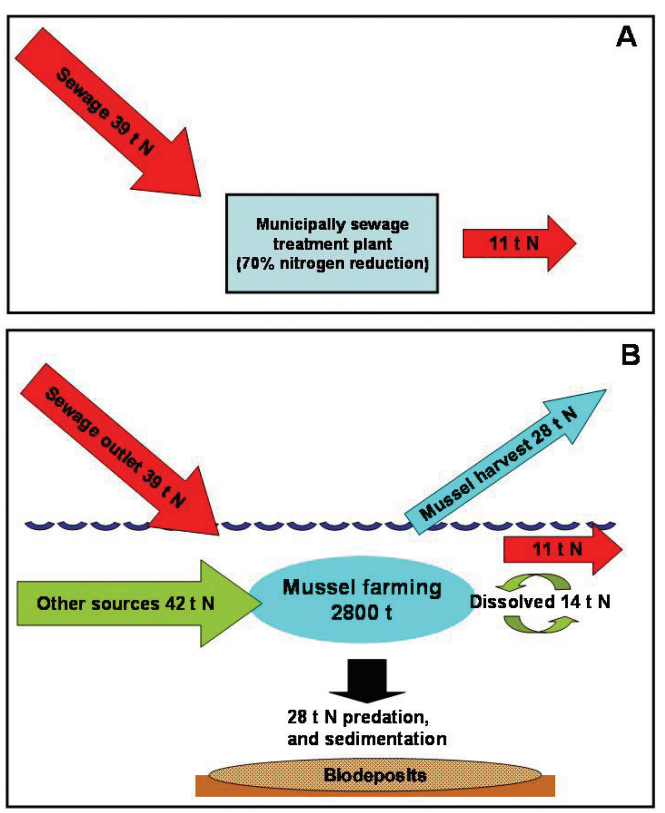

Figure 5. Nitrogen budgets in Lysekil assuming nitrogen removal: A) by the sewage treatment plant and B) by mussel farming (tonnes). 
off-shore will not fulfill this legal requirement. Further, from an ecological point of view it is essential that the catches of fish are made in the coastal zone in order to counteract the eutrophication. The trading of diffuse sources of nutrients will allow for more flexible solutions including fish landings, but the catches of stationary fish in the Swedish coastal zone are small and the contribution to a trading system will thus be small.

\section{Negative Environmental Effects}

There is no doubt that mussel farming will influence biogeochemistry and the benthic ecosystem below the farm through an increased load of organic material including mussels, feces from mussels, and other detritus $(27,30-34)$. The increased load may cause chemically reduced sediments and local areas with decreased oxygen concentrations. The size of the affected area as well as the degree of influence will depend on the amount of sedimentation and the local conditions like depth, bottom topography and bottom currents. The natural benthic fauna under a farm may be negatively influenced through a reduction of individuals, biomass, and species diversity. The negative effects are, however, restricted to near the farm and have to be judged in relation to the overall positive effects of using mussels to improve coastal ecosystem quality.

Site-specific and skilful management and operation of a mussel farm may reduce the negative effects on the benthic community below the farm and may even be totally beneficial through increasing the removal of nitrogen in the form of $\mathrm{N}_{2}$ gas by microbially mediated denitrification of the bivalve biodeposits (27). It will therefore be important to monitor the sediment status and development below a farm because ecological benefits associated with mussel farming are dependent on aerobic sediments and bioturbation.

\section{Farm Sites in the Lysekil Area}

Since the mussels are produced mainly for human consumption, farms cannot be located close to any sewage discharge. In the Lysekil area, farms are situated at protected sites at a distance of $1-10 \mathrm{~km}$ from any sewage treatment plant outfall. The water depths are between 8 and $20 \mathrm{~m}$. Current data from the area indicate an average current speed of $5 \mathrm{~cm} \mathrm{~s}^{-1}$ and more. Discussions with the local professional fishermen and suggestions during the public hearing led to some locations being excluded and others included as possible sites. The landowners have been positive when contacted. Overall, the plans have been positively received and many persons accept that the available marine resources are exploited.

\section{Social Benefits}

In comparison to mussel farming, wetland construction is labor intense during the initial phase. Thereafter, wetlands are not productive, nor do they give employment. The sewage plant is also initially labor intense and is not productive either, but will offer employment, in the Lysekil case, to one person at most. Farming mussels will produce a commercially attractive product and at the same time create jobs. An attempt to calculate the cost and benefits to society is shown below.

Production of $2800 \mathrm{t}$ of mussels would result in the removal of $28 \mathrm{t}$ of nitrogen as shown above. If the cost for the removal is set to $5.25 \mathrm{USD} \mathrm{kg}^{-1}$ nitrogen and at least 5 persons are directly engaged on a year round basis with an annual salary of 36600 USD, Table 1 shows the annual outcome.

The return to society in the form of tax is only 28000 USD short of the cost, if only the direct taxes for the employees are
Table 1. Calculation of difference between quota costs and total tax in USD.

$\begin{array}{ll}\text { Quota cost for removal of } 28 \text { tonnes of N } & 147000 \\ \text { Salaries for } 5 \text { employees (each } 36 \text { 600) } & 183000\end{array}$

$\begin{array}{lr}\text { Salaries for } 5 \text { employees (each } 36600) & 183000 \\ \text { Income tax (33\% of income) } & 60390\end{array}$

Employee tax (32\% of income) 58560

Total tax $\quad 118950$

Difference between quota cost and total tax $\quad-28050$

included. The enterprise producing the mussels will hopefully also create a profit thus improving the net return to society even further. The estimated net cost for the society in this case would only amount to $1 \mathrm{USD} \mathrm{kg}^{-1}$ of removed nitrogen.

\section{Economy and Market}

The economic basis of mussel production is to produce food for human consumption. European mussel production of 750 $000 \mathrm{t}$ annually accounts for about half the global production. The main producers are Spain, Denmark, Holland, France, and Italy. Smaal (35) discussed the status of the European production of mussels and concluded that many of the main production areas have reached saturation levels, due to a shortage of space or spat. He also mentioned recreation and nature conservation as limiting factors. He suggested Scotland, Ireland, Greece and Norway as possible locations for an expansion of the mussel industry. Smaal (35) also suggested that the demand for mussels will increase only slowly over the next few years. Most mussels produced in Europe are sold fresh. An increase in trade volumes can be foreseen if new markets are developed and if more processed products, such as ready meals, are added to the market. The economic success of a business with a production of $2800 \mathrm{t}$ of mussels depends on many factors, including the skill of the entrepreneurs and is beyond the scope of this paper. It can be concluded that the existing European market is very large and the proposed production of 2800 t constitutes only $0.4 \%$ of the total European production of blue mussels.

\section{Toxins}

Elevated levels of okadaic acid (OA) in blue mussels have been recorded along the Swedish west coast in varying amounts every year since 1983, when the first outbreaks were reported (36). Generally, concentrations of diarrhoeic shellfish toxins (DST) in mussels are low from March to August and moderate to high from October to January (Fig. 6). Some years, farms may be closed to harvesting for six months or

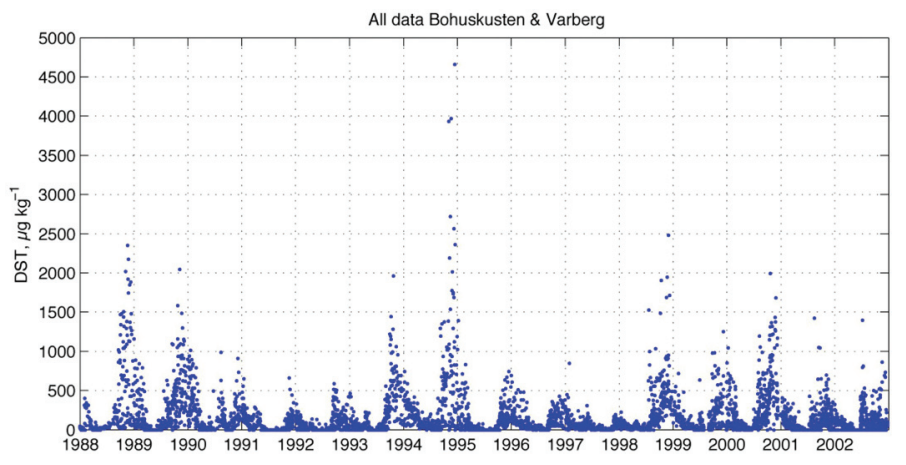

Figure 6. Seasonal variation of DST in mussels on the Swedish Skagerrak coast. With permission of Karlson, B., Rehnstam-Holm, A-S and Loo, L.O. Preliminary manuscript title: Temporal and spatial distribution of diarrheic shellfish toxins in blue mussels, Mytilus edulis (L.), along the Swedish Skagerrak coast, NE Atlantic. Reports Oceanography SMHI. 


\section{The Gullmar Fjord Bio-Geo-Chemical Model}

\section{Input to the model system.}

Geometry and time period: The Gullmar Fjord was chosen as a test basin/test period in 1994 mainly because of the existence of measurements for input and validation of the model results. The model includes the Gullmar Fjord and part of the coastal zone outside the fjord system.

The vertical resolution is $1 \mathrm{~m}$ from the surface down to $40 \mathrm{~m}$ depth. The layer thickness increases below that level to about $10 \mathrm{~m}$ at the bottom at $120 \mathrm{~m}$. The horizontal resolution is $12 \times 43$ cells as shown in the Figure. The model time step is 1 hour.

Initial properties of the water: The initial properties of the water are derived from measurements of salinity, temperature, nitrate, ammonium, phosphate, chlorophyll $a$ and oxygen inside and just outside the Gullmar Fjord. There are also variables in the model that are not measured, zooplankton, detritus, phosphorus and nitrogen at the bottom (nutrients available at the surface of the sediment). These variables are based on values from the measurements.

The incoming solar radiation: The solar radiation is important for driving both the biological processes and the temperature in the surface waters. The cloudiness, air temperature and humidity every third hour are derived from a databank at the Swedish Meteorological and Hydrological Institute (SMHI). The altitude of the sun at different times of the day and the year are computed internally in the model.

Inputs from land: Freshwater is added to the fjords from one major and five minor rivers. The freshwater flow and the contents of ammonium, nitrate and phosphate are taken from monthly measurements.

Inputs via the air: Airborne ammonium and nitrate inputs are added to the surface cells of the model. The information is taken from a climate model, which gives mean monthly values.

Inputs from the coastal zone: The water properties in the coastal waters are taken from monthly measurements at a standard monitoring station. Water with measured salinity, temperature, nutrient concentration, oxygen and chlorophyll concentration flows into the model with ingoing currents. When currents are directed out of the model the computed values are used.

Wind: Wind for wind stress computations are taken from an archive of measured wind velocities. The stress is set to zero during ice conditions.

\section{Ecological processes in the model.}

Oxygen can move in both directions between the atmosphere and the water.

Phytoplankton (one species) grows and multiplies by assimilation of nitrogen and phosphate.

Zooplankton (one species) feeds on phytoplankton and multiplies.

Bigger organisms feed on zooplankton.

Phytoplankton and detritus (dead matter) sink towards the bottom. A density gradient dampens the sinking velocity.

Turbulent mixing of salt, phytoplankton, nutrients, etc. is governed by a turbulence parameter, an eddy diffusivity, that is dampened by a computed density gradient and magnified by computed, vertical velocity gradients. High wind velocities create surface current gradients, which in turn increase the eddy diffusivity and eddy viscosity in the surface layers.

Plankton organisms excrete nitrogen and phosphate dissolved in water or as particles.

Bacteria decompose organic, dead matter in the water column or at the bottom and recirculate nitrogen and phosphate to the water.

There is a pool of inorganic matter available on the bottom.

Ammonium is oxidized to nitrate. Oxidized nitrate is denitrified to nitrogen gas, which is lost to the atmosphere.

A complete description of the ecological processes is found in Marmefelt et al. (23).

more when DST levels exceed the limit for consumption i.e. $160 \mu \mathrm{g} \mathrm{kg}^{-1}$ mussel, whereas the same site experiences only a short interruption of the harvest in other years $(9,37)$. There is also geographical variability in DST levels. When some farm sites are closed for production others are open. Hence, the industry can supply the market with toxin-free mussels most of the year by harvesting at different locations.

Manipulative experiments could not confirm any relationship between feeding and detoxification rates $(38,39)$, and found detoxification rates to be independent of temperature. Nevertheless, field and experimental data indicated that there was seasonal variability. For example, in August, a 50\% reduction in toxin content $\left(\mathrm{t}_{1 / 2}\right)$ was achieved after approximately 7 to 8 days compared to 16 days in November. This seasonal variability may be explained by differences in the physiological status and reproductive cycle of the mussel, which affects their physiological rate processes (40).

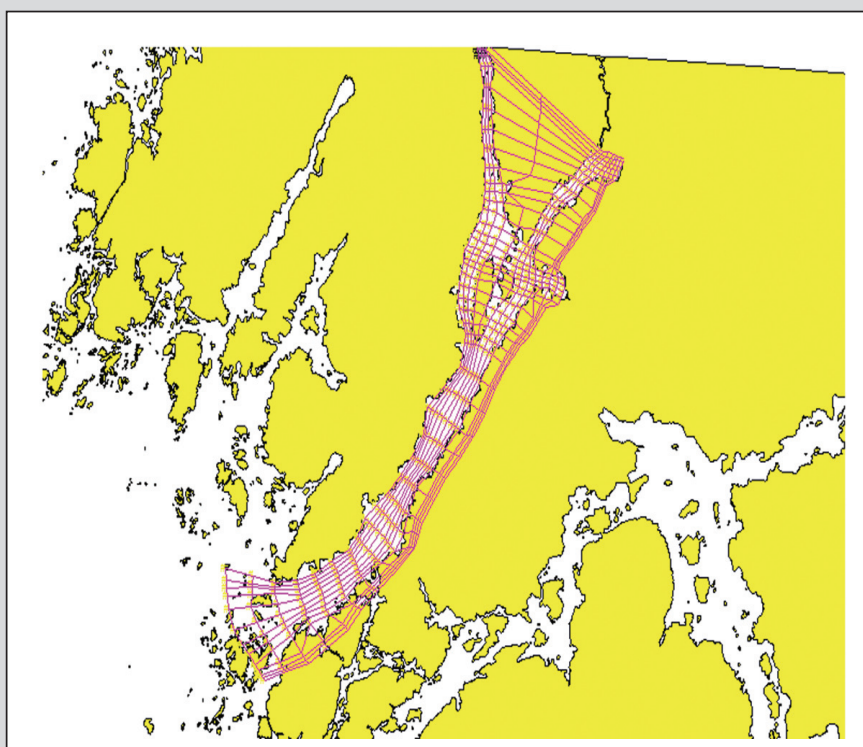

Figure. The grid of the Gullmar model.

From a management perspective, efforts should be put into developing land-based detoxification methods, where incoming water can be examined for potentially toxic species, and possibly filtered. A land-based system for detoxification of mussels can also be combined with live-storage facilities, where the mussel farmer has a possibility to store large quantities of mussels. Such as system has several economical benefits and can be used to further enhance the product quality apart from detoxification. For example, with the possibility to store mussels, the harvest can be co-ordinated and optimized in time and space. By storing the mussels for a few days, it has been observed that the mussels lose some of their byssal threads which makes them easier to separate (Scanfjord, pers. comm.) resulting in less damage and faster processing of the mussels in the production line. In the end, the cost of storage and detoxification in comparison to the cost of being unable to sell the mussels at periods will be decisive. 


\section{Result of Modeling}

The mussel farm acts as a sink for plankton and detritus and as a source of ammonium and detritus.

\begin{tabular}{|c|c|c|}
\hline & $\begin{array}{l}\text { Ton nitrogen } \\
\text { with mussel } \\
\text { farms }\end{array}$ & $\begin{array}{c}\text { Ton nitrogen } \\
\text { without mussel } \\
\text { farms }\end{array}$ \\
\hline Accumulation of nitrogen in the mussels & 50 & 0 \\
\hline Net transport out of the Gullmar Fjord & 252 & 317 \\
\hline Supply through land run-off & 414 & 414 \\
\hline Supply through atmospheric deposition & 27 & 27 \\
\hline Nitrogen content in fjord water & 66 & 59 \\
\hline Amount of PON sedimentation & 177 & 184 \\
\hline
\end{tabular}

The result of the model simulations showed that when 25 mussel farm units were introduced in the fjord and the mussels were harvested, the sedimentation of PON was reduced by $4 \%$ during the period January-October. The mussel farms had an even greater effect on the net transport of nitrogen (sum of dissolved and particulate) at the fjord mouth. The net outgoing transport was reduced by $20 \%$ or by 65 t during 10 months, which is about $1 / 4$ of the input of nitrogen from the major river (2/3 of land run-off) entering the Gullmar Fjord. The conclusion from the model is that large-scale mussel farming will have a substantial, positive effect on both sedimentation and export of nitrogen from the fjord.

\section{Agro-Aqua Recycling of Nutrients}

The results from the pilot study that fed mussels to laying hens showed that the hens preferred the mussel fodder over conventional organic hen fodder. The color of the yolk was intensified and no effect on the taste of the eggs was documented. Successful chicken and egg production demands that the fodder contains certain levels of the amino acid methionine, which at present cannot be maintained under complete organic production using only natural sources of this amino acid. It was calculated that in this pilot study half the daily demand of methionine was achieved from the mussel meat. The organic egg production industry has shown great interest in these results but the use of mussels for fodder needs to be further developed. The next step will be to develop a process for mussel meal production in order to achieve an organic product that may replace the fish meal in the fodder. It would be of special interest if mussels containing bio-toxins could also be used in this process. A first trial has demonstrated that production of mussel meal technically is a rather straight forward process. However, the economic potential of making mussel meal for fodder still needs to be investigated and evaluated.

The largest mussel-processing plant in Sweden has, for the last 10 years, transported the remainder to local farms, especially organic farms. The slurry was stored "fresh" in containers and delivered free to each farmer 5-10 times per year, who typically applied about $10 \mathrm{t} \mathrm{ha}^{-1}$. The material had a bad smell but in general the farmers were pleased with the results: increased growth of crops, positive effects on soil structure and increased $\mathrm{pH}$ were observed. The slurry also contained a number of essential micronutrients $(12,41)$.

An increase in the quantity of the slurry means that new techniques have to be developed to handle it. A closed composting system at the site of the mussel processing plant would be desirable, in order to minimize the smell while retaining the nutritional value. Such a system would be able to deliver an attrac- tive and easy-to-handle product when needed by farmers and gardeners, and may at best pay its own costs or at least reduce the cost for the mussel industry.

\section{CONCLUSION}

In order to investigate ways of encouraging the expansion of mussel production, and to find cost-effective solutions, it is essential to map all sources and sinks of nitrogen that are regulated and paid today. This involves a constructive and cross-boundary dialogue with decision-making bodies such as the local and national government authorities as well as the European Community authority.

The necessary knowledge and expertise exists to implement large-scale mussel farming as a means for improving marine coastal water quality. The main challenge seems to be to persuade the relevant civil service departments and ministries (Environment, Agriculture and Finance) and the European Commission that mussel farming is a simple, flexible and cost-effective measure to counter marine eutrophication. No other single measure seems to be available which may contribute as much as mussel farming in order to reach the environmental goals established by the Swedish government for coastal marine ecosystems. Compared to other measures, the added benefits of mussel farming for society are striking at the same time as the negative effects for the environment are minor and acceptable.

\section{References and Notes}

1. Diaz, R.J. and Rosenberg, R. 1995. Marine benthic hypoxia. A review of its ecological effects and the behavioral responses of benthic macrofauna. Oceanogr Mar. Biol. Ann. Rev. 245-303.

2. Cloern, J.E. 2001. Our evolving conceptual model of the coastal eutrophication problem. Mar. Ecol. Prog. Ser. 210, 223-253.

3. Rosenberg, R. 1990. Negative oxygen trends in Swedish coastal bottom waters Mar. Pollut. Bull. 21, 335-339.

4. SMHI. 2001. The Skagerrak - Environmental State and Monitoring Prospects ISBN 91-89507-04-5. (Swedish Meteorological and Hydrological Institute, (SMHI).

5. County Board of Administration, Västra Götaland, Sweden. 2003. Miljömålen Västra Götaland Rapport 2003: 19. (The Environmental Goals in Västra Götaland). (In Swedish). www.o.lst.se/miljoma

6. Brandt, M. and Ejhed, H. 2003. Transport-Retension - Källfördelning - Belastning på Havet. Naturvårdsverket Rapport 5247. Transport - Retension - Source Distribution - Load on the Sea. (In Swedish)

7. Anon. 2003. Havet - Tid för en Ny Strategi (The Sea - Time for A New Strategy) Statens offentliga utredningar SOU 2003:72. (In Swedish, English summary).

8. Ryther, J.H., Dunstan, W.M., Tenore, K.R. and Huguenin, J.E. 1972. Controlled eutrophication: increased food production from the sea by recycling human wastes. Bio. Sci. 22, 144-152.

9. Haamer, J. 1995. Presence of the phycotoxin okadaic acid in mussels (Mytilus edulis) in relation to nutrient composition in Swedish coastal water. J. Shellfish Res. 14, 209-216

10. Edebo, L., Haamer, J., Lindahl, O., Loo, L.-O. and Piriz, L. 2000. Recycling of macronutrients from sea to land using mussel cultivation. Environ. Pollut. 13 $190-207$.

11. SCB (Statistiska Centralbyrån. 2003. Yearbook of Agricultural Statistics. Statistics Sweden (In Swedish). http://www.scb.se

12. Lutz, R.A. (ed.) 1980. Mussel Culture and Harvest: a North American Perspective. Elsevier Scientific Publishing Company, Amsterdam.

13. Lindahl, O., Belgrano, A. and Malmgren, B.A. 2003. Increased phytoplankton production in the Gullmar Fjord, Sweden, 1985-1999. ICES MSS Vol. 219, $387-$ 389 .

14. Loo, L.-O. and Rosenberg, R. 1983. Mytilus edulis culture: growth and production in western Sweden. Aquaculture 35, 137-150

15. Ackefors, H. and Haamer, J. 1987. A new Swedish technique for culturing blue mussel. ICES C.M. 1987/K. Shellfish Committee. Ref. Mariculture Committee.

16. Haamer, J. 1995. Phycotoxin and Oceanographic Studies in the Development of the Swedish Mussel Farming Industry. PhD thesis, Depts of Oceanography and Clinical Bacteriology, Göteborg University, Sweden.

17. Ellegård, A. and Ungfors, A. 1999. Conflicts in Coastal Fishery - A Case Study from the Swedish West Coast. Göteborg University, Human Ecology Report Series, HERS SUCOZOMA Report 1999:2

18. Kollberg, S. 2000. The Swedish Mussel Industry. Swedish Aquaculture Association, Gothenburg, Sweden, $75 \mathrm{pp}$.

19. Andersen, P., Hald, B. and Emsholm, H. 1996. Toxicity of Dinophysis acuminato in Danish coastal waters. In: Harmful and Toxic Algal Blooms. Yasumoto, T. Oshima, Y. and Fukuyo, Y. (eds). Intergovernmental Oceanographic Commission of UNESCO pp. 281-284

20. Rippey, S.R. 1994. Infectious diseases associated with molluscan shellfish consumption. Clin. Microbiol. Rev. 7, 419-425.

21. Lees, D. 2000. Viruses in bivalve shellfish. Int. J. Food Microbiol. 59, 81-116. 22. Lee, R.J. and Morgan, O.C. 2003. Environmental factors influencing the micro- 
biological contamination of commercially harvested shellfish. Water Sci. Technol. 47, 65-70.

23. Marmefelt, E., Håkansson, B. Erichsen, A.C. and Sehlstedt-Hansen, I. 2000. De velopment of an Ecological Model System for the Kattegat and the Southern Baltic. SMHI Report Oceanography, No. 29, 2000.

24. Svensson J. 2002. Validering av en Biogeokemisk 3-dimensionell Modell över Gullmarsfjorden, 1994. SMHI Rapport Nr. 16. Validation of a 3D biogeochemical model of the Gullmar Fjord, 1994. (In Swedish).

25. Pearce, D.W. and Turner, R.K. 1990. Economics of Natural Resources and the Environment. Johns Hopkins University Press. Harvester Wheatsheaf, Herts, UK.

26. Tietenberg, T. 2003. Environmental and Natural Resource Economics 6/E. Addison-Wesley, Reading, MA, USA.

27. Newell, R.I.E. 2004. Ecosystem influences of natural and cultivated populations of suspension feeding bivalve mollusks: a review. J. Shellfish Res. 23, 51-61.

28. Chesapeake Bay Program. Chesapeake Bay Program Office, Annapolis, MD, USA www.cheasapeakebay.net/trading.htm

29. County Board of Administration, Västra Götaland, Sweden. 2002. Projekt Våt mark och Skyddszoner - Projektredovisning 1998-2001, Dals-Eds kommun Munkedals kommun, Färjelanda kommun. Project Wetland and Protective Zones - Project Report 1998-2001, Dals-Ed Community, Munkedal Community and Färgelanda Community. Länsstyrelsen i Västra Götaland. (In Swedish).

30. Hatcher, A., Grant. J. and Schofield, B. 1994. Effects of suspended mussel culture (Mytilus spp.) on sedimentation, benthic respiration and sediment nutrient dynamics in a coastal bay. Mar. Ecol. Prog. Ser. 115, 219-235.

31. Grant, J., Hatcher, A., Scott, D.B., Pocklington, P., Schafer, C.T. and Winters, G.V. 1995. A multidisciplinary approach to evaluating impacts of shellfish aquaculture on benthic communities. Estuaries 18, 124-144

32. Mirtho, S., La Rosa, T., Danavaro, R. and Mazzola A. 2000. Microbial and meiofaunal response to intensive mussel-farm biodeposition in coastal sediments of the western Mediterranean. Mar. Pollut. Bull. 40, 244-252.

33. La Rosa, T., Mirto, S., Marino, A., Alonzo, V., Maugeri, T.L. and Mazzola, A. 2001. Heterotrophic bacteria community and pollution indicators of mussel-farm impact of the Gulf of Gaeta (Tyrrhenian Sea). Mar. Environ. Res. 52, 310-321.
34. La Rosa, T., Mirto, S., Favaloro, E., Savona, B., Sarà, G., Danovaro, R. and Mazzola, A. Impact on the water column biogeochemistry of a Mediterranean mussel and fish farm. Water Res. 36, 713-721.

35. Smaal, A.C. 2002. European mussel cultivation along the Atlantic coast: production status, problems and perspectives. Hydrobiologia 484, 89-98.

36. Haamer, J., Andersson, P.-O., Lindahl, O., Lange, S., Li, X. P. and Edebo, L. 1990. Geographic and seasonal variation of Okadaic acid content in farmed mussels, Mytilus edulis Linnaeus, 1758, along the Swedish west coast. J. Shellfish Res. 9, 103-108.

37. Lindegarth, M. 1997. Sammanställning och Tolkning av de Kontinuerliga Mätningarna av Okadasyrahalter Längs den Svenska Västkusten. (Compilation and Evaluation of the Continuous Measurements of Ocadaic Acid along the Swedish West Coast). The Water Quality Association of the Bohus Coast, Uddevalla, Sweden. (In Swedish).

38. Svensson, S. 2003. Depuration of Okadaic acid (Diarrhetic Shellfish Toxin) in mussels, Mytilus edulis, feeding on different quantities of non-toxic algae. Aquaculture $218,277-29$

39. Svensson, S. and Förlin, L. 2004. Analysis of the importance of lipid breakdown for elimination of okadaic acid (diarrhetic shellfish toxin) in mussels, Mytilus edulis: results from a field study and a laboratory experiment. Aquatic Toxicol. $66,405-418$.

40. Hawkins, A.J.S. and Bayne, B.L. 1992. Physiological interrelations and the regulation of production. In: The Mussel Mytilus: Ecology, Physiology, Genetics and Culture Gosling, E. (ed.). Elsevier, Amsterdam, pp. 171-222.

41. Rosenberg, R. and Loo, L.O. 1983. Energy-flow in a Mytilus edulis culture in western Sweden. Aquaculture 35, 151-161.

42. The authors would like to thank the MISTRA programme "Sustainable Coastal Zone Management", project 2:1 and the EC Interreg IIIA-programme "Gränslöst Samarbete", project GS3041-45-02, for funding. We are also grateful to two unknown referees. Further we would like to thank Maj Persson for the drawings and Candida Savage for the linguistic correction.
Odd Lindahl is biological oceanographer and marine ecologist employed by the Royal Swedish Academy of Sciences since 1978. He has been working on plankton production in relation to climate variability, the ecology of HAB-species and marine monitoring but turned his interest into methods to improve coastal water quality. His address: Kristineberg Marine Research Station, Kristineberg 566, SE-450 34 Fiskebäckskil, Sweden odd.lindahl@kmf.gu.se

Rob Hart is an environmental economist and has worked as a lecturer at SLU, the Swedish University of Agricultural Sciences, since 2003. His main research interest is technological change, economic growth, and the environment. His address: SLU Box 7013, SE-750 07 Uppsala, Sweden.

rob.hart@ekon.slu.se

Bodil Hernroth is a biomedical scientist employed by The Royal Swedish Academy of Sciences since 1983. Her main research interests are transmission of pathogens to humans through consumption of bivalves and invertebrate immunology. Her address: Kristineberg Marine Research Station, Kristineberg 566, SE-450 34 Fiskebäckskil, Sweden

bodil.hernroth@kmf.gu.se

Sven Kollberg is an aquaculturist and has worked on various tasks for the development of the aquaculture sector in Sweden. He is now focusing on the production of commercially interesting commodities from farmed mussels. His address: Kristineberg Marine Research Station, SE- 45034 Fiskebäckskil, Sweden.

svenkollberg@telia.com

Lars-Ove Loo is a marine ecologist and has worked as a scientist at Tjärnö Marine Biological Laboratory and Kristineberg Marine Research Station in periods since 1980. His address: Göteborg University, Tjärnö Marine Biological Laboratory, SE-452 96 Strömstad, Sweden.

lars.-ove.loo@tmbl.gu.se
Lars Olrog is adviser in ecological and organic farming at The Rural Economy and Agricultural Societies and teacher at Dingle College of Rural Education. He has been involved in field experiments using mussel waste as an organic fertilizer.

His address: Naturbruksgymnasiet i Dingle, SE-450 52 Dingle, Sweden.

lars.olrog@vgregion.se

Ann-Sofi Rehnstam-Holm is a molecular biologist and microbiologist with research interests in marine bacteria and toxic microalgae, but also in human pathogens and their spread in nature. Her address: Institution of Mathematics and Science, Kristianstad University, SE- 28143 Kristianstad, Sweden. ann-sofi.rehnstam-holm@mna.hkr.se

Jonny Svensson is an oceanographer with experience of environmental planning and monitoring in coastal waters and has assessed the effects on water transport of the bridge construction in Öresund. He was employed for 30 years by the Swedish Meteorological and Hydrological Institute (SMHI) and is now working for a consulting company. His address: Thalassos Computations, Linneavägen 7, SE-437 31, Lindome, Sweden.

jonny.svensson@hem.utfors.se

Susanne Svensson is a zoophysiologist and has worked as a scientist at Göteborg University since 1997. Her main research is on effects and dynamics of algal toxins in marine bivalves. Her address: Tjärnö Marine Biological Laboratory, 45296 Strömstad, Sweden susanne.svensson@tmbl.gu.se

Ulf Syversen is a scientist in chemistry and natural resources and has worked at several Norwegian institutions and companies with research and development. The focus has been technical and business development in relation to sustainable use of natural resources. His address: Østfold Sustainable Development, P.O. Box 123, N-1601 Fredrikstad, Norway ulsy@interconsult.com 